Uluslararası Mühendislik

Araştırma ve Geliştirme Dergisi

International Journal of

Engineering Research and

Development
UMAGD, (2022) 14(1), 10-23.

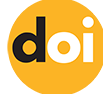

10.29137/umagd. 895498

Cilt/Volume:14 Sayı/Issue:1 Ocak/January 2022

Araştırma Makalesi / Research Article

\title{
Design, Manufacturing and Testing of a Stirling Engine with Slider-Crank Mechanism
}

\author{
Hayri Yaman ${ }^{1}$ iD , Derviş Erol ${ }^{1}$ i \\ Department of Automotive Technology, Kırlkkale Vocational School, Kırlkkale University, Kırlkkale, 71450, Turkey
}

Başvuru/Received: 12/03/2021

Kabul / Accepted: 05/10/2021

Çevrimiçi Basım / Published Online: 31/01/2022

Son Versiyon/Final Version: 31/01/2022

\begin{abstract}
In this study, a beta type Stirling engine with slider-crank mechanism having swept volume of $365 \mathrm{~cm}^{3}$ was designed, manufactured and performances tested. The design phase was first started by determining the operating parameters of the engine. The necessary mathematical calculations were performed by considering the operating conditions of the Stirling engine with a slider-crank mechanism to be manufactured. After determining the engine parameters, the dimensional design phase was started within the tolerance limits of the engine parts. The parts were designed by the computer-aided SolidWorks program in solid modeling and by the AutoCAD program in two-dimensional design and projecting. Each part used in the manufacturing of the Stirling engine was assembled delicately in the assembly process. A prony-type dynamometer, liquefied petroleum gas (LPG) fuel, and electronically controlled electric heater systems were developed to perform the performance tests and analyses of the manufactured engine. Experimental studies were conducted at hot end temperatures of $627^{\circ} \mathrm{C}, 727^{\circ} \mathrm{C}$, and $827^{\circ} \mathrm{C}$ and at a cold end temperature of $27^{\circ} \mathrm{C}$ by utilizing an electrical heater as a heat source and air as a working fluid. According to the results obtained in experimental studies for different heater temperatures and different charge pressures, it was revealed that engine power values increased depending on the heater temperature and charge pressure increase. The maximum power values at all heater temperatures were acquired at a charge pressure of 4 bar. In this study, the maximum engine power was obtained as $69.5 \mathrm{~W}$ at a hot end temperature of $827^{\circ} \mathrm{C}$, at a charge pressure of $4 \mathrm{bar}$, and at an engine speed of $200 \mathrm{rpm}$ when a stainless-steel displacement piston and air as a working fluid were utilized, and the maximum engine torque value was obtained as $4.21 \mathrm{Nm}$ at a charge pressure of $4 \mathrm{bar}$ and an engine speed of 135 $\mathrm{rpm}$. The lowest engine power among the maximum engine power values obtained in all experimental studies was found as 17.09 $\mathrm{W}$ at a hot end temperature of $627^{\circ} \mathrm{C}$, at a pressure of $1 \mathrm{bar}$, and at an engine speed of $185 \mathrm{rpm}$. The maximum power values of the engine developed within the scope of this study at hot end temperatures of $627^{\circ} \mathrm{C}, 727{ }^{\circ} \mathrm{C}$, and $827^{\circ} \mathrm{C}$ were determined to be 31.2 $\mathrm{W}, 48.3 \mathrm{~W}$, and $69.5 \mathrm{~W}$, respectively. Upon examining the results obtained from experimental studies, it is observed that the heater temperature and charge pressure have significant impacts on the performance values of Stirling engines. Within the scope of this study, a new power generation system that could use renewable energy sources was put into operation.
\end{abstract}

\section{Key Words}

"Stirling engines, Slider-crank mechanism, Engine design and manufacturing, Stirling engine testing" 
Nomenclature

\begin{tabular}{|c|c|}
\hline Dd & displacer cylinder bore ( $\mathrm{mm})$ \\
\hline $\mathrm{Dp}$ & power cylinder bore (mm) \\
\hline Dr & displacer rod bore $(\mathrm{mm})$ \\
\hline hd & displacer piston length (mm) \\
\hline hp & power piston length (mm) \\
\hline $\mathrm{Ht}$ & cylinder length (mm) \\
\hline $\mathrm{J}$ & joule \\
\hline ldr & displacer rod length (mm) \\
\hline $\operatorname{lr}$ & connecting rod length of rhombic $(\mathrm{mm})$ \\
\hline $\mathrm{m}$ & mass of working fluid \\
\hline $\mathrm{n}$ & engine speed (rpm) \\
\hline $\mathrm{Nm}$ & newton meter \\
\hline $\mathrm{P}$ & pressure (bar) \\
\hline$Q_{\text {in }}$ & heat transfer inlet \\
\hline$Q_{\text {out }}$ & heat transfer outlet \\
\hline$Q_{\text {Rin }}$ & heat transfer regenerator inlet \\
\hline$Q_{\text {Rout }}$ & heat transfer regenerator outlet \\
\hline $\mathrm{R}$ & gas constant $(\mathrm{kJ} / \mathrm{kgK})$ \\
\hline $\mathrm{T}$ & temperature $(\mathrm{K})$ \\
\hline $\mathrm{T}_{\mathrm{H}}$ & heater temperature $(\mathrm{K})$ \\
\hline $\mathrm{T}_{\mathrm{L}}$ & cooler temperature $(\mathrm{K})$ \\
\hline rpm & revolutions per minute \\
\hline $\mathrm{V}$ & volume \\
\hline $\mathrm{W}$ & watt \\
\hline
\end{tabular}

Abbreviations

AISI

American Iron and Steel Institute

$\mathrm{CNC}$

Computer Numerical Control

DIN

Deutsches Institut für Normung

LPG

Liquid Petroleum Gas

SAE

Society of Automotive Engineers

MSC Adams

Microsoft Software Corporation Automatic Dynamic Analysis of Mechanical System 


\section{Introduction}

Along with the increase in population in the world, the difficulties in meeting the energy demand are increasing every day. Power generation processes reveal many harmful emissions to the ecosystem (Hansen et al. 2019). When fossil-based fuels are used, large amounts of greenhouse gases, especially carbon dioxide, carbon monoxide and hydrocarbon are emitted into the atmosphere (Guelpa et al. 2019; Lin and Zhu, 2019; Nathaniel and Iheonu, 2019). Renewable energy sources, such as solar, wind, wave, tide, geothermal and biomass, are used to reduce greenhouse gas emissions. Nowadays, the importance of using energy effectively and efficiently is increasing every day (Gielen et al. 2019; Krakowski et al. 2016; Ozcan et al. 2018). Considering these adverse reasons, the ability of Stirling engines to run with all types of fuel provides an advantage in comparison with other energy generating systems. From another point of view, the fact that Stirling engines can convert waste heat energies released into the environment from factory chimneys or systems producing with high heat into mechanical energy is considered to be a significant gain in the efficient use of energy (Çinar et al. 2012; Erol et al. 2021).

Robert Stirling designed and manufactured a beta type Stirling engine running on the principle of external heat dissipation in 1816. This engine was officially registered with patent No. 4081 (Stirling, 1816). The output power of $2 \mathrm{hp}$ was obtained from the beta type engine in having a swept volume of $0.103 \mathrm{~m}^{3}$ using flue gases at $255^{\circ} \mathrm{C}$ under atmospheric conditions (Finkelstein and Organ, 2004; Organ, 2014). In 1818, this type of Stirling engines, which run more efficiently than steam engines, was used in water pumps in the mining sector. Air was used as the working fluid in the first Stirling engines, and these engines were named "Air engine" (Çınar et al. 2012; Urieli and Berchowitz, 1984). In the 1860s, Wilhelm Lehmann conducted many studies on single-cylinder beta type Stirling engines. In the 1930s, studies on developing Stirling engines were initiated again in Philips Research Laboratories to produce a little, silent, economic, and practice electric generator for the purpose of meeting the electrical needs of radios. It is observed that until the 1950s, single-cylinder Stirling engines with a slider-crank mechanism were designed and manufactured in Philips laboratories to be used as cooling machines (Rinia and Pre, 1946; Brey et al. 1947; Weenen, 1947; Meijer, 1965). Due to these reasons, very extensive research and studies are conducted to develop machines that can use renewable energy sources that may replace fossil fuels and are not dependent on the fuel type. Nowadays, the development process of Stirling engines is continued by companies and universities operating in many different countries (Erol et al. 2017).

There are few studies in the literature examining the engine performance characteristics of the slider crank drive mechanism used in Stirling engines. It is possible to summarize these studies in the following way.

Çınar, C. et al. conducted the design, manufacture, and performance tests of a beta-type Stirling engine with a slider crank drive mechanism. It was indicated that experimental studies were carried out at heater temperatures of $800{ }^{\circ} \mathrm{C}, 900{ }^{\circ} \mathrm{C}$, and $1000{ }^{\circ} \mathrm{C}$ using ambient air as a working fluid at atmospheric pressure in this manufactured engine. It was explained that the Stirling engine started running at a hot end temperature of $650{ }^{\circ} \mathrm{C}$. According to the results obtained in experimental studies, it was reported that the maximum engine power was acquired as $5.98 \mathrm{~W}$ at $208 \mathrm{rpm}$ when the heater temperature was $1000^{\circ} \mathrm{C}$ (Çınar et al. 2005). Cheng, C. H. et al. investigated the thermal efficiency of a beta-type Stirling engine with a slider crank drive mechanism by employing a numerical model and carried out the design study by conducting the theoretical analysis of the engine (Cheng and Yu, 2011). Gheith, R. et al. conducted the design, manufacture, and performance tests of a beta-type Stirling engine with a slider crank drive mechanism. Torque, speed, and power values were examined under different conditions by utilizing air as the working fluid for experimental studies in this engine. The theoretical results obtained in the study were compared with the findings of the experimental studies. Furthermore, it was declared that the performance results of the manufactured engine as a cooling machine were examined (Gheith et al. 2011). Reséndiz-Antonio, M., and Santillán, M. developed a detailed mathematical model that simply addressed all the thermodynamic and mechanical details of a Stirling engine with a slider crank drive mechanism and formed the basis for studying engine performance and conducted its theoretical analysis (Reséndiz-Antonio and Santillán, 2014). Araoz, J. A. et al. developed a numerical simulation covering all thermodynamic, thermal, and mechanical interactions of a two-cylinder Stirling engine with a slider crank drive mechanism. Within the scope of this study, possible adverse effects limiting the engine performance characteristics were attempted to be determined. The findings obtained from the theoretical study were compared with the experimental results of the engine. According to the results obtained from the theoretical study, it was reported that the design changes made in the engine caused an improvement of approximately $26 \%$ in the performance (Araoz et al., 2015). Barreto, G. and Canhoto, P. carried out a study aiming to determine the energy generation and efficiency of a beta-type Stirling engine with a slider crank drive mechanism running on solar energy using a parabolic dish. In this study, they theoretically investigated the modeling and simulation of the system, including the thermodynamic and energy transfer processes in the Stirling engine, all the main processes occurring in the compression, expansion and regenerator spaces and investigated their effects on the engine's performance. It was explained that the optimization model suggested in the research could be easily adjusted to the dimensions and operating conditions of a Stirling engine with higher power outputs. Furthermore, it was reported that it was possible to obtain higher performance characteristics by improving some negative aspects of the thermal receiver and Stirling engine (Barreto and Canhoto, 2017). Erol, D., and Çalışkan, S. performed the kinematic and thermodynamic analyses of bell crank, slider crank, rhombic drive, and scotch yoke drive mechanisms for a beta-type Stirling engine with a swept volume of $365 \mathrm{~cm}^{3}$ under the same conditions. It was reported that the kinematic analyses of each mechanism were examined using the MSC Adams program, and the pressure-volume changes depending on the crankshaft angle were calculated by employing the isothermal analysis method. Moreover, the study explained that the effects of the working fluid mass, charge pressure, and heater temperatures on the net work amount obtained for each mechanism during a cycle were examined in detail by conducting thermodynamic analyses. The theoretical results of the performance characteristics of these different drive mechanisms were compared graphically (Erol and Çalışkan, 2019). 
In this study; a beta type Stirling engine with a slider-crank mechanism having a swept volume of $365 \mathrm{~cm}^{3}$ was designed, manufactured and performances tested. Basic calculations and computer-aided 3-dimensional (3D) modeling of the engine with the determined design dimensions were realized. Material selection was made depending on the operating conditions of the parts before manufacturing. The values showing which parts will be heat-treated and which of them will run between precision machining machines and tolerance values were determined, and manufacturing processes were initiated. Many parts of the engine were machined directly on the CNC machine. Casting molds were prepared for some engine parts, and the preparation of semi-finished products was ensured, and then they were machined on the $\mathrm{CNC}$ machine. The assembly of each part manufactured within the manufacturing dimensional tolerance limits was performed starting from the main body of the engine. Furthermore, the engine performance characteristics of a beta-type Stirling engine with a slider crank drive mechanism were determined by utilizing air as the working fluid and an electrical heater as a heat source under laboratory conditions.

\section{Material and Methods}

Within the scope of this study, the design and manufacturing drawings of a beta type Stirling engine with a slider-crank mechanism, for which a prototype would be manufactured, were performed using the SolidWorks program, which is a computer-aided design program. The drawings of the designed Stirling engine with a slider-crank mechanism in SolidWorks environment from different angles are presented in Fig. 1. The cycle in beta type Stirling engines is realized by the displacer piston and concentric power piston running in the same cylinder, as is shown in Fig. 1. The cylinder volume in this type of engines is divided into two as compression and expansion volumes by means of displacer piston. Technical specifications of the manufactured Stirling engine with a slider-crank mechanism are presented in Table 1.
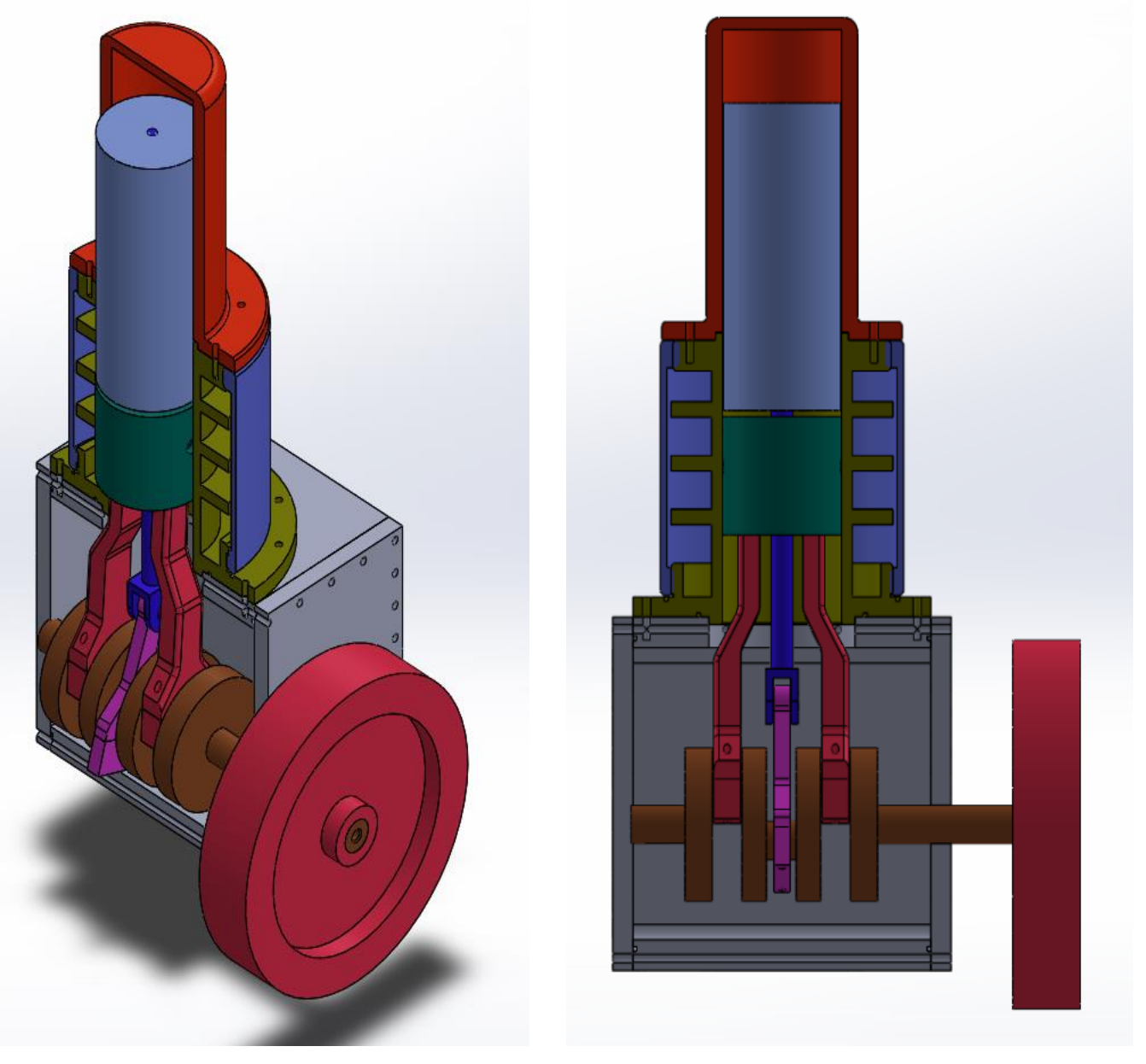

Figure 1. Schematic view of beta type Stirling engine with a slider-crank mechanism 
Table 1. Technical specifications of Stirling engine

\begin{tabular}{lc}
\hline \multicolumn{1}{c}{ Parameters } & Specification \\
\hline Engine type & Beta \\
Drive mechanism & Slider-crank \\
Swept volume $\left(\mathrm{cm}^{3}\right)$ & 365 \\
Displacer cylinder bore, Dd (mm) & 88 \\
Displacer piston bore (mm) & 87 \\
Displacer piston length, hd (mm) & 200 \\
Displacer piston stroke (mm) & 60 \\
Power cylinder bore, Dp (mm) & 88 \\
Power piston bore (mm) & 88 \\
Power piston length, hp (mm) & 32.5 \\
Power piston stroke (mm) & 60 \\
Cylinder length, Ht (mm) & 514 \\
Displacer rod length, ldr (mm) & 189 \\
Displacer rod bore, Dr (mm) & 16 \\
Displacer connecting rod length, ld (mm) & 95 \\
Power piston connecting rod length, lp (mm) & 205 \\
Displacer crank radius, Rd (mm) & 30 \\
Power piston crank radius, Rp (mm) & 30 \\
\hline
\end{tabular}

\subsection{Working principle and basic cycle of the Stirling engine}

Stirling engines run as closed cycles on the basis of generating power during the repetition of the heating and cooling processes of the working fluid isolated from external environment. Working fluid exhibits behaviors defined by gas laws (related to pressure, temperature, and volume). When the gas is heated, pressure increases, and it generates power by affecting the power piston since it is in an isolated area. When the gas is cooled, pressure decreases, and as a result of this, the piston uses a part of the work formed to recompress the gas on the return stroke. The resulting net work creates the useful output power on the spindle. The working fluid is transferred periodically between hot and cold heat exchangers. The working fluid was insulated within the engine cylinders. Therefore, there is no exhaust gas in this type of engines. Unlike other piston engines, there is also no need for valves.
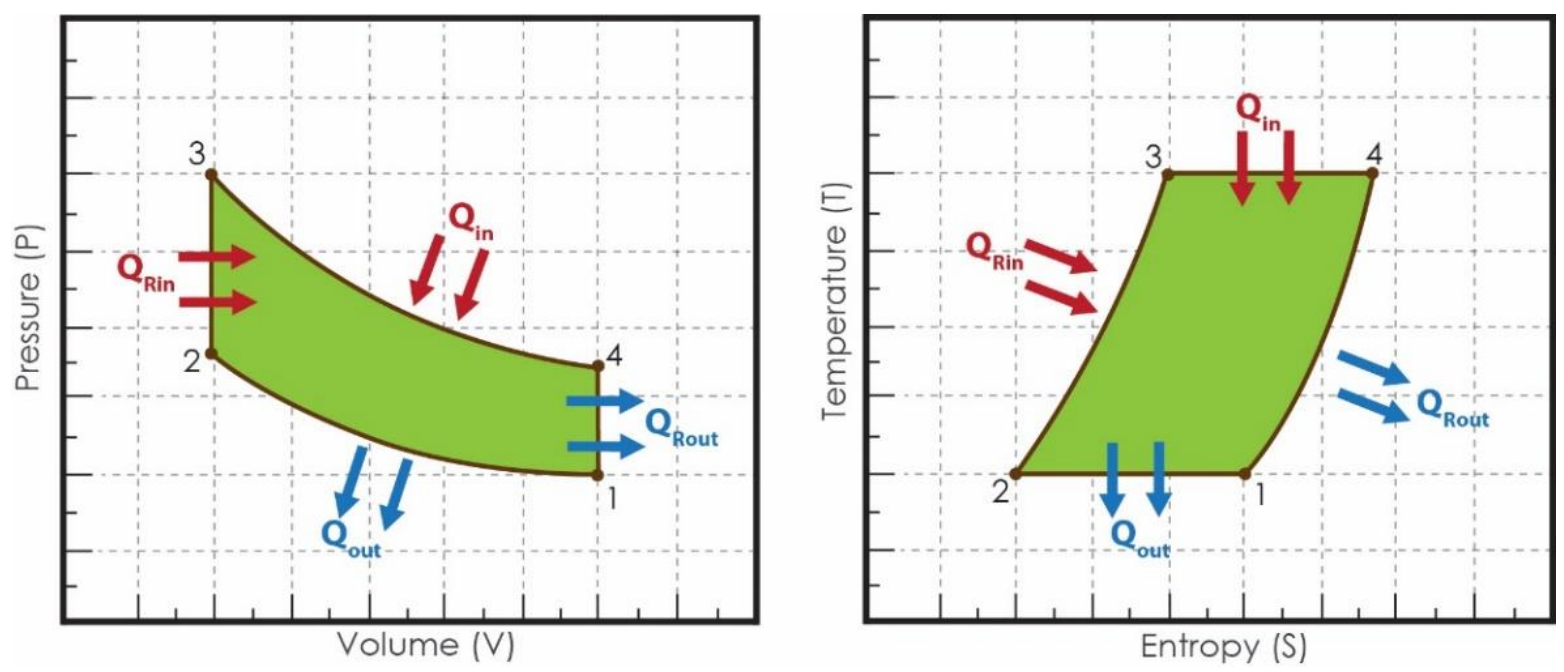

Figure 2. P-V and T-S diagram of Stirling cycle with regenerator (Erol et al. 2017). 
The Stirling engine cycle pressure-volume (P-V) and temperature-entropy (T-S) working relationships are observed in Fig. 2. Volume and pressure changes are taken into account in the work calculations. In the calculation of transferred heat, specific heat, temperature, and volume changes in a constant volume are used.

Process 1-2: Compression at constant temperature and heat transfer from system to external environment

Process 2-3: Heat is supplied to system from an external source in a constant volume

Process 3-4: Expansion at constant temperature and continuation of the heat supply to the system

Process 4-1: Heat transfer from system to external environment in a constant volume

\subsection{Design and manufacturing of a beta type Stirling engine}

The explanations and schematic drawings of the material properties of the engine block and side covers, crankshaft, power cylinder, power piston, displacement cylinder and piston, displacement piston power take-off, connecting rods, and flywheel, which form the basic parts of the engine, are presented below. The assembly of manufactured beta type Stirling engine is shown in Fig. 3.

Engine block was determined as the casting material, and mold design was made. The engine block was cast into the prepared mold. The semi-finished engine block that emerged from the casting was manufactured in a CNC machine as a single piece at the desired dimensions and tolerances, resistant to a 10-bar pressure working fluid. The design and manufacturing drawings of the manufactured engine block are presented in Fig. 4 and Fig. 5. The two sides of the engine block were closed by two covers bearing the crankshaft.
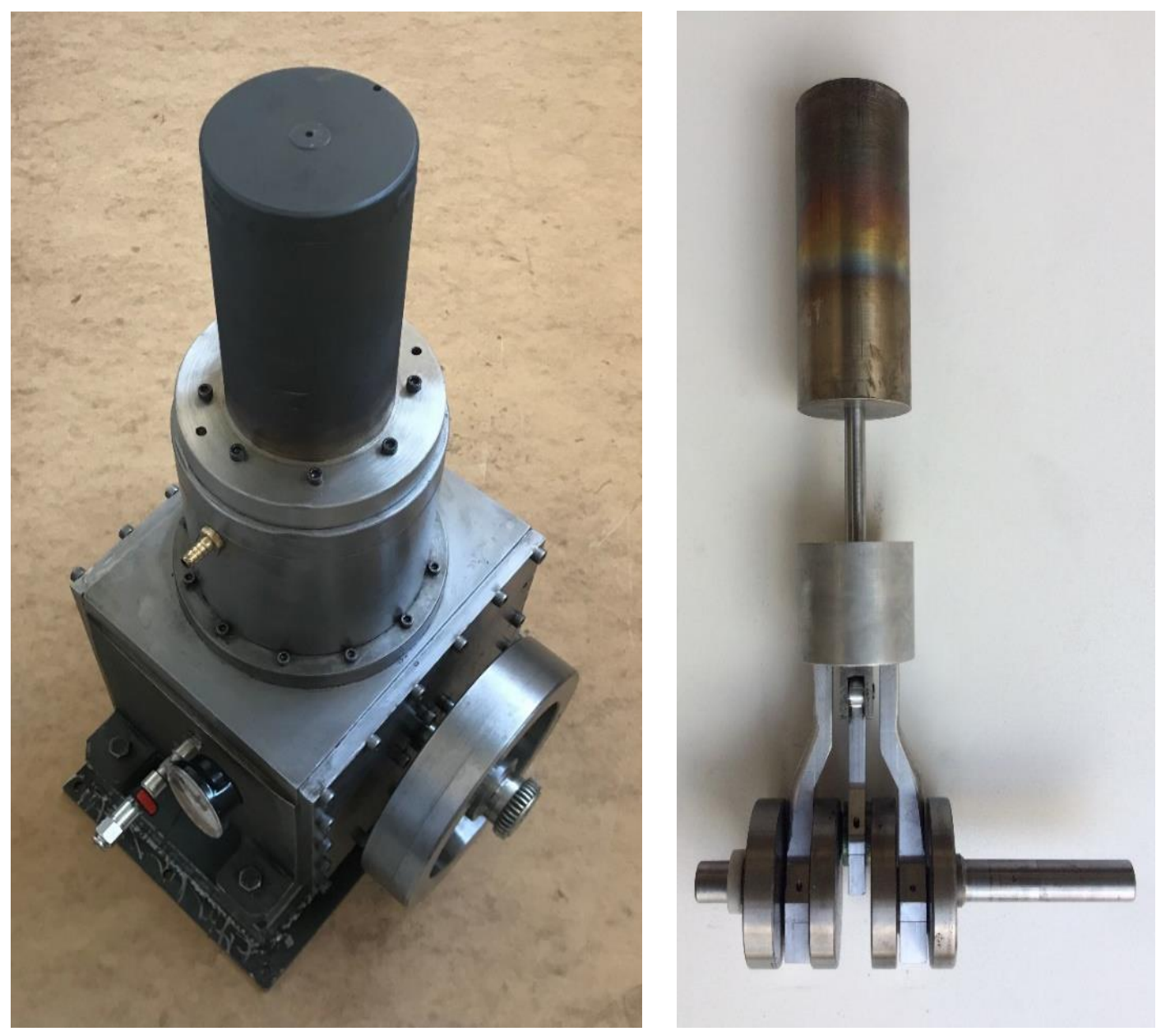

Figure 3. Assembly views of the prototype Stirling engine with a slider-crank mechanism 

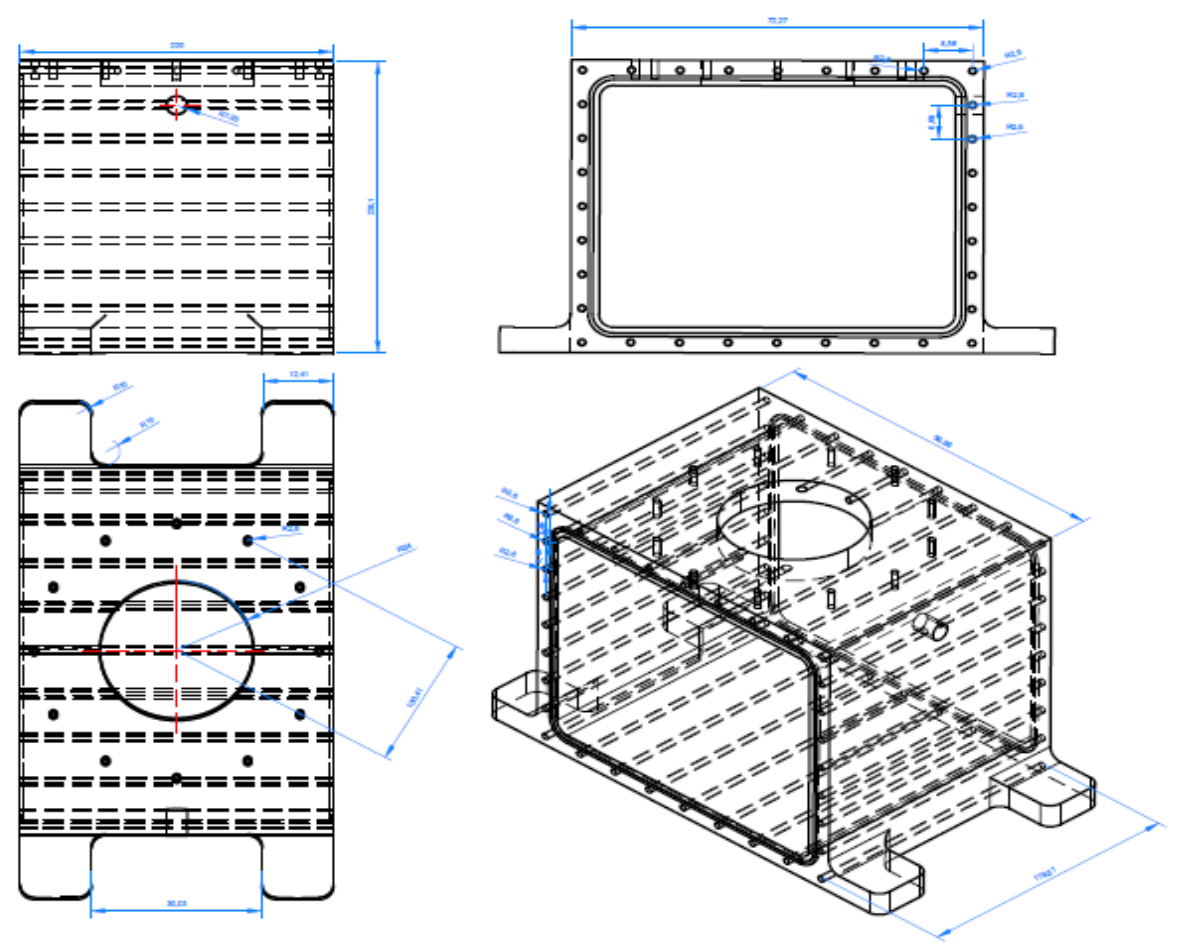

Figure 4. Schematic drawing of the designed engine block
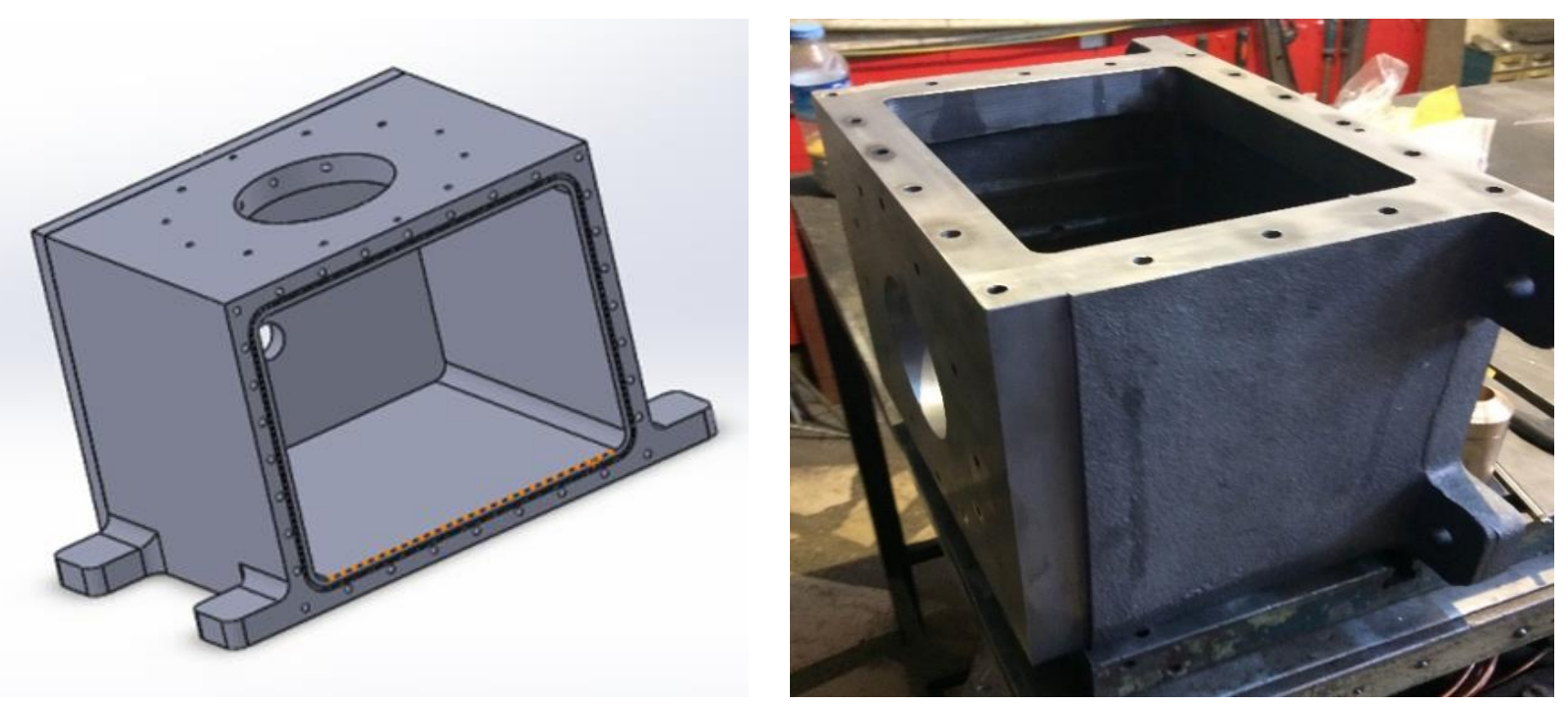

Figure 5. Three dimensional solid model and actual views of the engine block

The crankshaft was manufactured in one piece of the AISI/SAE 4140 material, and its journal surfaces were precisely ground. While the dynamic balance of the crankshaft was connected to the horizontal balancing device, the part was made by being unloaded over the balance weights. After the crankshaft journals subjected to balancing were ground, the surface quality was improved by polishing. The outer rings of the tapered bearings on the main journals of the crankshaft were placed on the centering bearings found on the covers of the block. The covers fix the crankshaft through the tapered bearings on both sides. The design and manufacturing drawings of the crankshaft are presented in Fig. 6. The flywheel was manufactured of the AISI/SAE 1040 (DIN C40 tempered steel) material. 

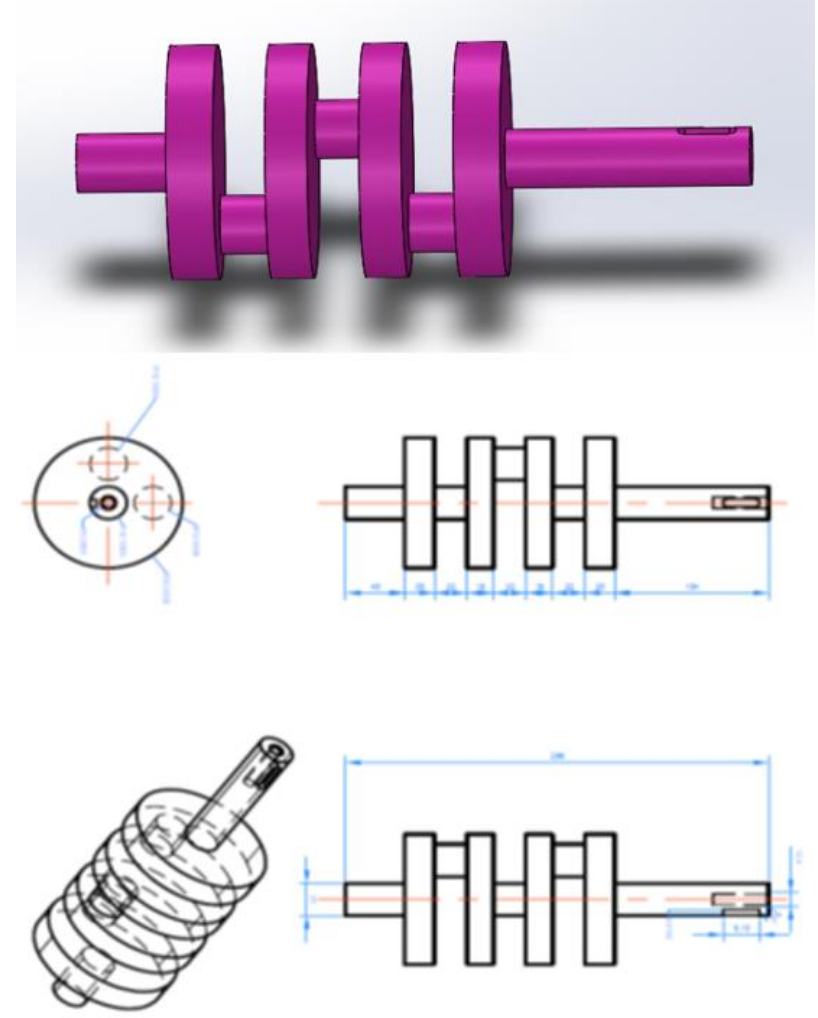

Figure 6. General views of the crankshaft designed in the SolidWorks environment

The power cylinder and cooler body were manufactured in two pieces of the AISI/SAE 303 material. Heat treatment was applied to this part to increase the frictional resistance between the piston and cylinder. The power piston was manufactured in one piece of the 7075 series aluminum alloy. A piston ring was not used to ensure sealing in the power piston. To provide sealing, the outer surface of the power piston was manufactured precisely, and a running clearance of $0.05 \mathrm{~mm}$ was provided between it and power cylinder. Power piston and displacer connecting rods were manufactured in two parts of the 7075 series aluminum alloy. Since the rod of the displacer piston passed through the middle of the power piston of beta type Stirling engines, it was turned and machined precisely by placing bronze material in the middle of the power piston. In this way, mechanical losses were minimized by ensuring the sealing of better quality between rod of displacer piston and rod of power piston.
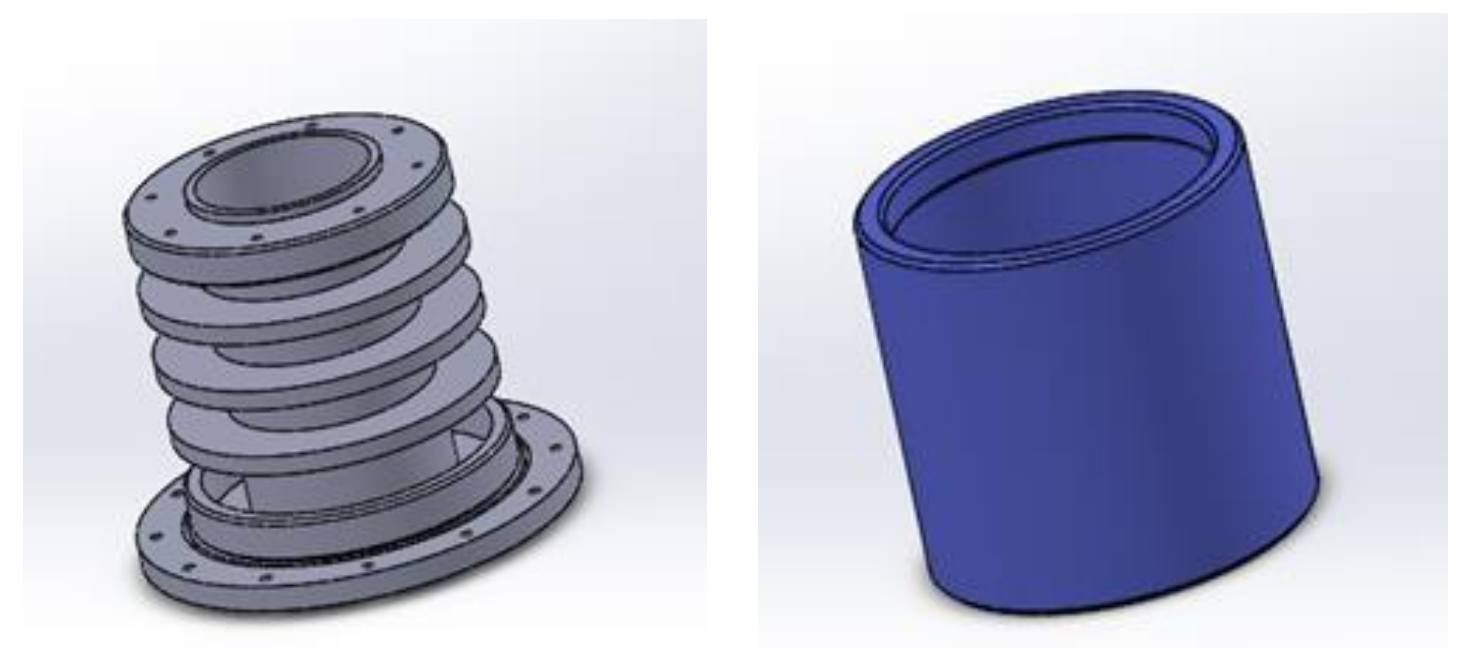

Figure 7. Power cylinder and cooler designed in the SolidWorks environment 
The displacer pistons were manufactured of the AISI/SAE 303 pipe material. The outer surface of one of these pistons was covered with zirconium oxide to ensure thermal insulation. The design and manufacturing drawings of the displacer piston are shown in Fig. 8. An uncoated stainless-steel displacer piston was utilized in the experimental studies.

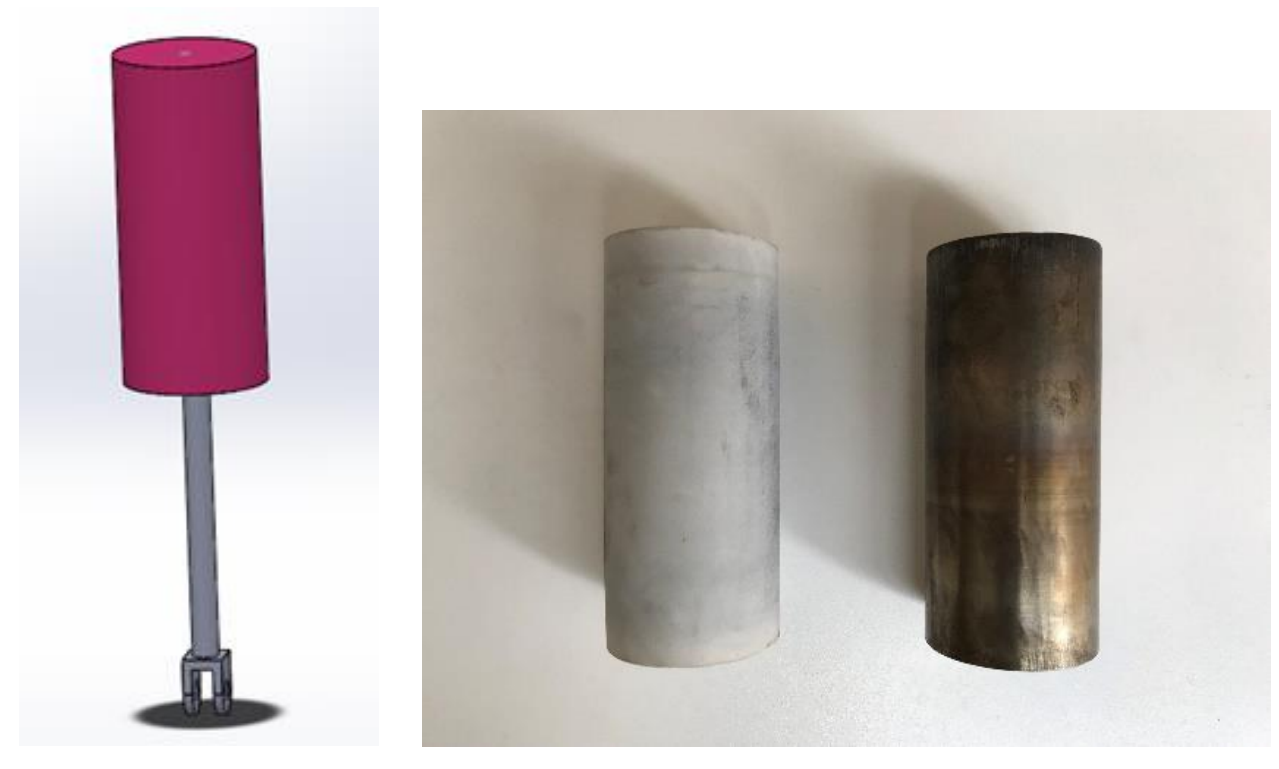

Figure 8. Assembly view of the displacer piston and the fitting part

The displacer cylinder was manufactured in one part of the AISI/SAE 303 (DIN X8CrNiS18-9 stainless steel) material. The displacer cylinder was connected to the power cylinder with the help of 8 socket head M6 bolts. To ensure sealing, the liquid gasket was used on the surfaces where the displacer cylinder contacted with the power cylinder. The bottom part of displacer cylinder was manufactured with flanges for the ease of assembly and better sealing. The design and manufacturing drawings of the displacer cylinder are shown in Fig. 9 and Fig. 10.

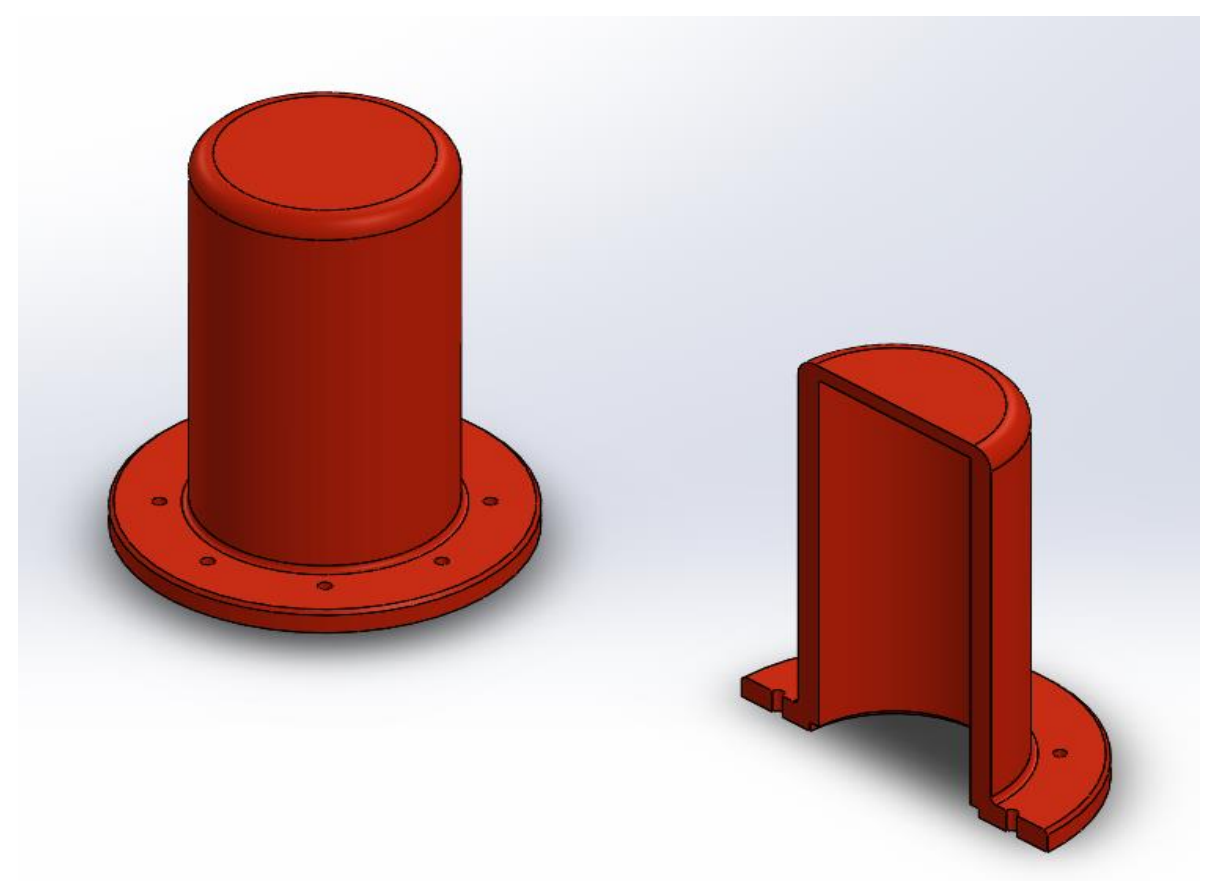

Figure 9. Schematic drawing of displacer cylinder designed in the SolidWorks environment 


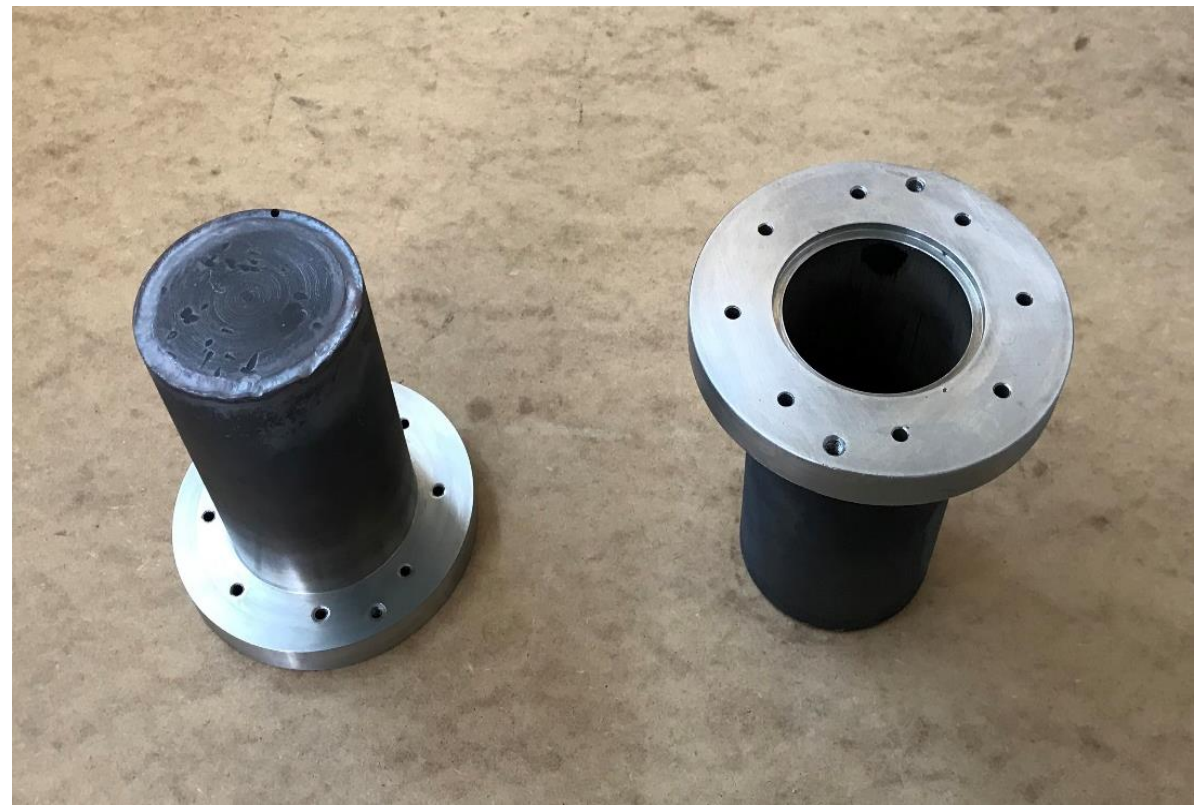

Figure 10. Schematic view of the manufactured displacer cylinder

\subsection{Test systems developed for the manufactured Stirling engine}

After the manufacturing processes, the engine assembly was performed in the laboratory environment. After the engine assembly was completed, the necessary environments were created in the laboratory of the Automotive Technology Department of Kirikkale University to be able to perform experimental studies, and two different experimental setups were prepared. A Prony-type dynamometer, liquefied petroleum gas (LPG) fuel, and electronically controlled electric heater systems were developed to conduct the performance tests and analyses of the manufactured engine.

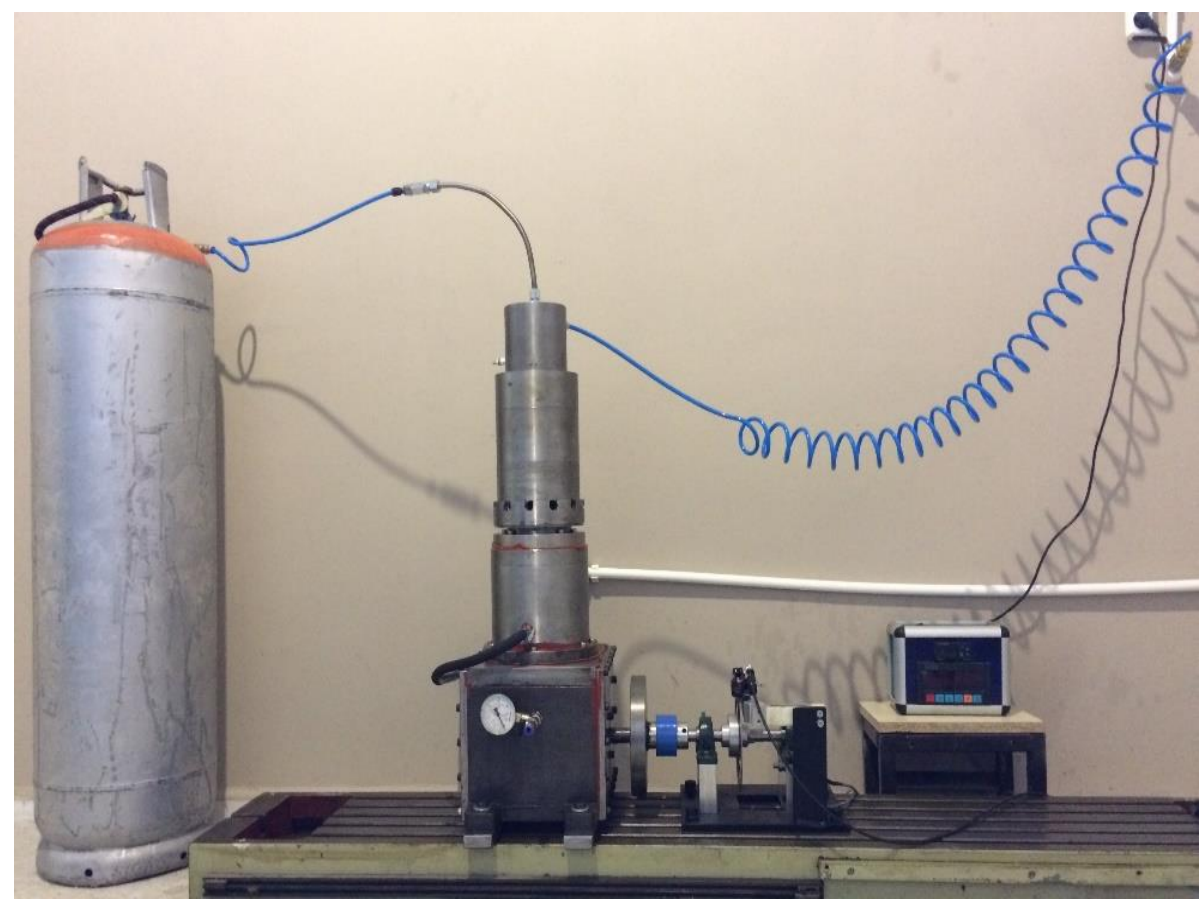

Figure 11. Experimental setup using liquefied petroleum gas (LPG) 


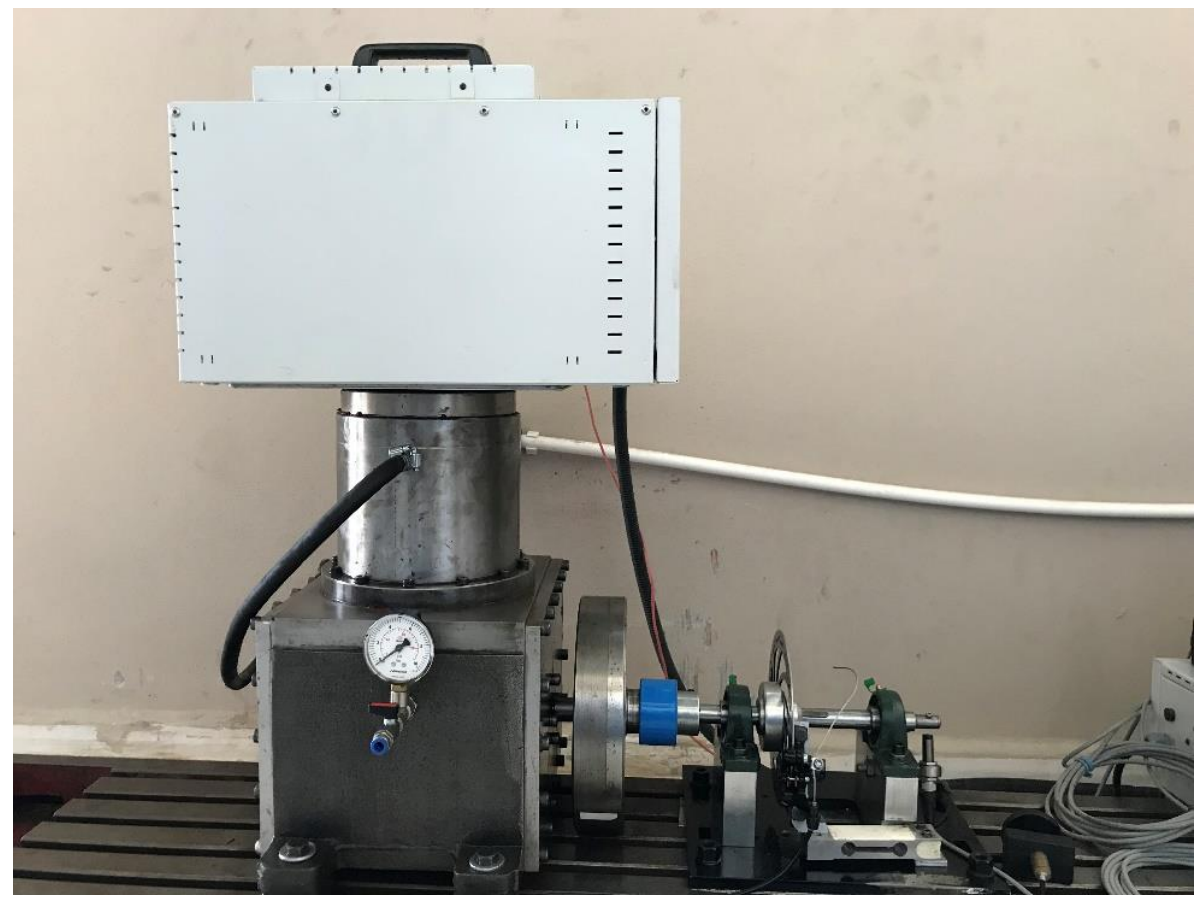

Figure 12. Experimental setup using an electronically controlled electric heater

\section{Experimental Studies and Performance Tests}

In this study, the design, manufacture, and performance tests of a beta-type Stirling engine with a slider-crank mechanism with a swept volume of $365 \mathrm{~cm}^{3}$ were carried out. The performance tests of the manufactured Stirling engine were conducted at hot end temperatures of $627{ }^{\circ} \mathrm{C}, 727^{\circ} \mathrm{C}$, and $827^{\circ} \mathrm{C}$ and at a cold end temperature of $27^{\circ} \mathrm{C}$, using an electrical heater and air as a working fluid. Water was used as a cold source. The results obtained in the experimental studies performed for different heater temperatures and different charge pressures are presented in Fig. 13, Fig. 14, and Fig. 15. According to the results obtained, it was revealed that the engine power values increased depending on the increase in the heater temperature and charge pressure. The maximum power values at all heater temperatures were acquired at a charge pressure of 4 bar.

Upon examining the graphs, it was observed that the engine power values obtained at a charge pressure of 5 bar were lower than the values obtained at a charge pressure of 4 bar. Experimental studies were tried to be conducted at a charge pressure of 6 bar. However, since excessive power losses in the engine were observed, experimental studies were carried out for charge pressures of 1-5 bar. The reason for the decrease in the engine power after 4 bar due to the increased charge pressure is the loss of engine performance due to the insufficient heating and cooling times needed for the working fluid because of the increase in the amount of working fluid in the cylinder.

In all experimental studies performed in this research, low engine power values were obtained due to the lack of a sufficient amount of the working fluid in the cylinder at low charge pressures. When the graphs are examined in detail, it is observed that the engine power obtained at low speeds for each charge pressure is higher than that obtained at high speeds. The reason for this originates from the fact that the heating and cooling times required for the working fluid are adequate at low engine speeds, while the heating and cooling times required for the working fluid are not adequate at high engine speeds due to the increase in speed. Hence, a certain part of the power that can be produced from the engine is lost in this way.

The maximum engine power was acquired as $69.5 \mathrm{~W}$ at a hot end temperature of $827^{\circ} \mathrm{C}$, at a charge pressure of 4 bar, and at an engine speed of $200 \mathrm{rpm}$, and the maximum engine torque value was obtained as $4.21 \mathrm{Nm}$ at a charge pressure of $4 \mathrm{bar}$ and at an engine speed of $135 \mathrm{rpm}$. The lowest engine power among the maximum engine power values obtained from all experimental studies was determined to be $17.09 \mathrm{~W}$ at a hot end temperature of $627^{\circ} \mathrm{C}$, at a pressure of $1 \mathrm{bar}$, and at an engine speed of $185 \mathrm{rpm}$. During the experimental studies, the best performance values were obtained at a hot end temperature of $827^{\circ} \mathrm{C}$ and a charge pressure of 4 bar. Upon examining the results obtained in the experimental studies, it is observed that the heater temperature and charge pressure significantly affect the performance values of Stirling engines. To improve the operating parameters of Stirling engines, it is of great importance to design special heaters and heat exchangers in order to transfer the heat energy taken from the hot source to the working fluid at maximum efficiency. Moreover, it is desired that the working fluid used in Stirling engines has a high thermal conductivity and a low density. 

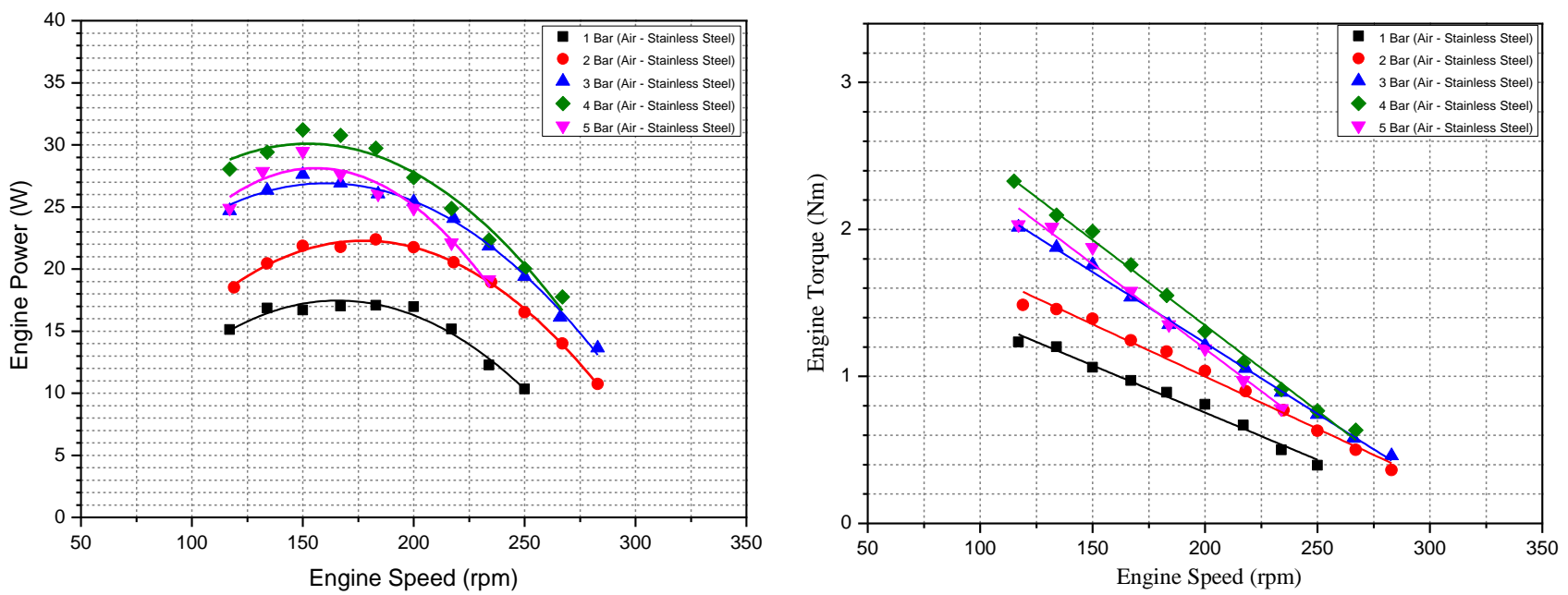

Figure 13. The variations of engine power and torque at different charge pressure $\left(627^{\circ} \mathrm{C}\right)$
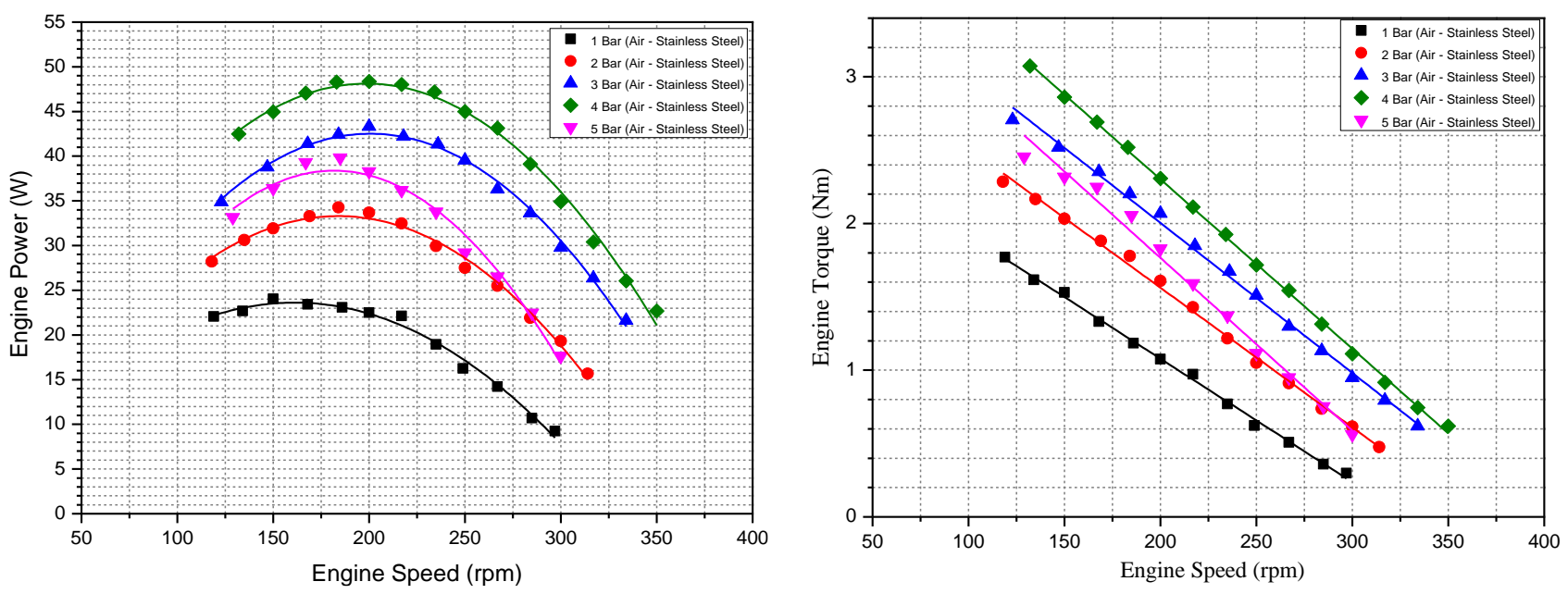

Figure 14. The variations of engine power and torque at different charge pressure $\left(727^{\circ} \mathrm{C}\right)$
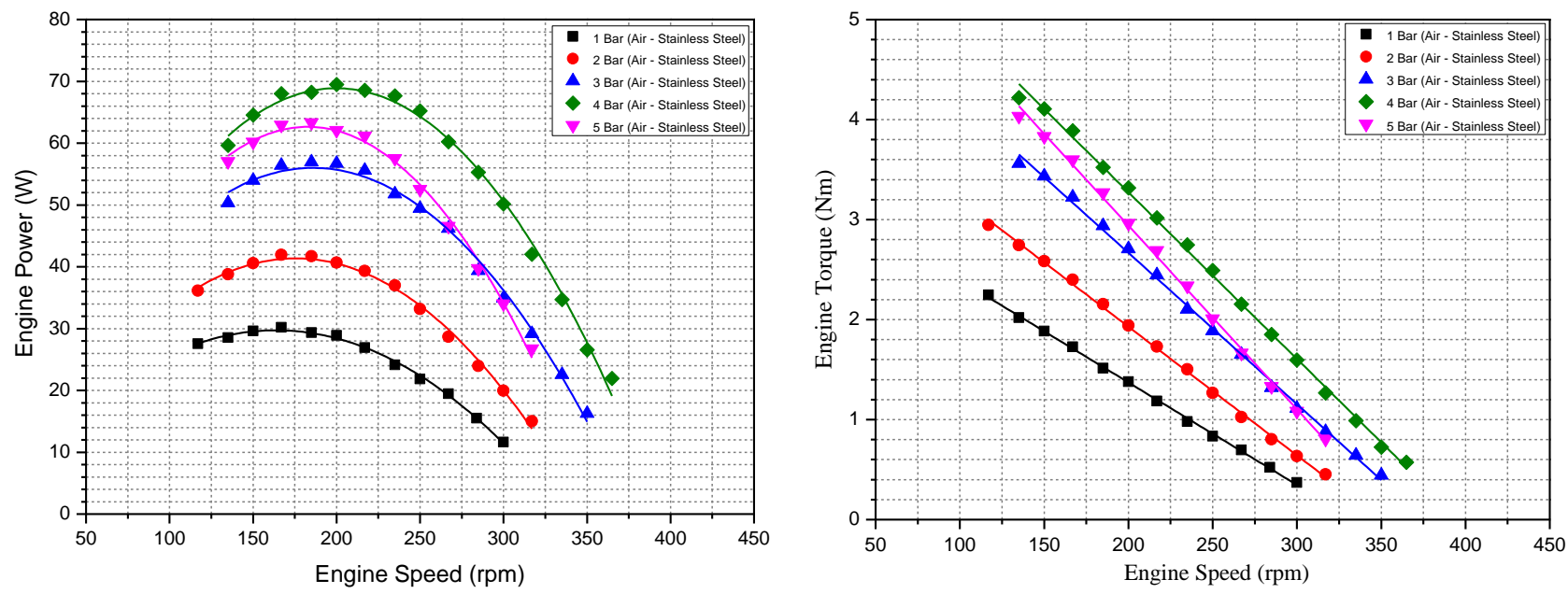

Figure 15. The variations of engine power and torque at different charge pressure $\left(827^{\circ} \mathrm{C}\right)$ 


\section{Conclusions}

In this study, a beta type Stirling engine with a slider-crank mechanism having a swept volume of $365 \mathrm{~cm}^{3}$ was designed, manufactured, and testing. The engine parts, of which solid models were created before manufacturing, were assembled in the SolidWorks design program, and the theoretical study simulations of the engine were performed. The conditions that would affect the operating conditions in the cyclical test simulation of the engine were re-evaluated in the SolidWorks program, and the necessary design corrections were applied. After the design study was completed, the parts of the Stirling engine were produced with advanced technology CNC manufacturing techniques by selecting materials suitable for the operating conditions. After the manufacturing processes, the assembly of the engine parts was performed in the laboratory environment. After the engine assembly was completed, the necessary environments were created in the laboratory of the Automotive Technology Department of Kırıkkale University to conduct experimental studies, and two different experimental setups were prepared. Unlike internal combustion engines, Stirling engines are systems that generate power using all kinds of heat energy sources. A Prony-type dynamometer, liquefied petroleum gas (LPG) fuel, and electronically controlled electric heater systems were developed to conduct the performance tests and analyses of the manufactured engine. Experimental studies were carried out with air as working fluid. Torque and engine power output changes were acquired depending on the engine speed, heater temperature, and charge pressure. The maximum engine power was acquired as $69.5 \mathrm{~W}$ at a hot end temperature of $827{ }^{\circ} \mathrm{C}$, at a charge pressure of $4 \mathrm{bar}$, and at an engine speed of $200 \mathrm{rpm}$, and the maximum engine torque value was obtained as $4.21 \mathrm{Nm}$ at a charge pressure of 4 bar and at an engine speed of $135 \mathrm{rpm}$. The lowest engine power among the maximum engine power values obtained from all experimental studies was determined to be $17.09 \mathrm{~W}$ at a hot end temperature of $627^{\circ} \mathrm{C}$, at a pressure of $1 \mathrm{bar}$, and at an engine speed of $185 \mathrm{rpm}$. During the experimental studies, the best performance values were obtained at a hot end temperature of $827^{\circ} \mathrm{C}$ and a charge pressure of 4 bar.

\section{Acknowledgment}

This study was supported within scope of the projects numbered 2016/020 by the Kırıkkale University Scientific Research Projects Coordination Unit. We would like to thank Kırıkkale University Scientific Research Projects Coordination Unit for their financial support.

\section{References}

Araoz, J. A., Salomon, M., Alejo, L., and Fransson, T. H. (2015). Numerical simulation for the design analysis of kinematic Stirling engines, Applied Energy, 159:633-650.

Barreto, G., and Canhoto, P. (2017). Modelling of a Stirling engine with parabolic dish for thermal to electric conversion of solar energy, Energy Conversion and Management, 132:119-135.

Brey, H. D., Rinia, H., Weenen, F. L.V. (1947). Fundamentals for the development of the Philips air engine, Philips Technical Review, 9(4):97-104.

Cheng, C. H., and Yu, Y. J. (2011). Dynamic simulation of a beta-type Stirling engine with cam-drive mechanism via the combination of the thermodynamic and dynamic models, Renewable Energy, 36(2):714-725.

Çınar, C., Yucesu, S., Topgul, T., and Okur, M. (2005). Beta-type Stirling engine operating at atmospheric pressure, Applied Energy, 81(4):351-357.

Çınar, C., Aksoy, F., Erol, D. (2012). The effect of displacer material on the performance of a low temperature differential Stirling engine, International Journal of Energy Research, 36:911-917.

Erol, D., Yaman, H. and Doğan, B. (2017). A review development of rhombic drive mechanism used in the Stirling engines. Renewable and Sustainable Energy Reviews, 78:1044-1067.

Erol, D., and Çalışkan, S. (2019). Comparative study on the performance of different drive mechanisms used in a beta type Stirling engine through thermodynamic analysis, International Journal of Automotive Engineering and Technologies, 8(2):44-60.

Erol, D., Doğan, B., and Çalışkan, S. (2021). The investigation of an energetic and exergetic performance characteristics of a beta-type Stirling engine with a rhombic drive mechanism. Journal of the Brazilian Society of Mechanical Sciences and Engineering, 43(4):119.

Finkelstein, T. and Organ, A. J., Air engines the history science and reality of the perfect engine. The American Society of Mechanical Engineers, New York, 2004. 
Gheith, R., Aloui, F., and Nasrallah, S. (2011). Experimental study of a beta Stirling thermal machine type functioning in receiver and engine modes, Journal of Applied Fluid Mechanics, 4(2):32-42.

Gielen, D., Boshell, F., Saygin, D., Bazilian, M.D. and Wagner, N. (2019). The role of renewable energy in the global energy transformation, Energy Strategy Reviews, 24:38-50.

Guelpa, E., Bischi, A., Verda, V., Chertkov, M., Lund, H. (2019). Towards future infrastructures for sustainable multi-energy systems: A review, Energy, 184:2-21.

Hansen, K., Mathiesen, B.V., Skov, I. R. (2019). Full energy system transition towards 100\% renewable energy in Germany in 2050, Renewable and Sustainable Energy Reviews, 102:1-13.

Krakowski, V., Assoumou, E., Mazauric, V. and Maïzi, N. (2016). Feasible path toward 40-100\% renewable energy shares for power supply in France by 2050: A prospective analysis, Applied Energy, 171:501-522.

Meijer, R. J. (1965). Philips Stirling engine activities, SAE Technical Paper (No. 650004).

Lin, B., Zhu, J. (2019). Determinants of renewable energy technological innovation in China under $\mathrm{CO}_{2}$ emissions constraint, Journal of Environmental Management, 247:662-671.

Nathaniel, S. P., Iheonu, C. O. (2019). Carbon dioxide abatement in Africa: The role of renewable and non-renewable energy consumption. Science of The Total Environment, 679:337-345.

Organ, A. J., (2014). Stirling cycle engines inner workings and design. John Wiley and Sons, Ltd, (ISBN:9781118818435).

Ozcan, M. (2018). The role of renewables in increasing Turkey's self-sufficiency in electrical energy. Renewable and Sustainable Energy Reviews, 82, 2629-2639.

Reséndiz-Antonio, M., and Santillán, M. (2014). On the dynamical vs. thermodynamical performance of a $\beta$-type stirling engine, Physica A: Statistical Mechanics and its Applications, 409:162-174.

Rinia, H., Pre, F. K. D. (1946). Air engines, Philips Technical Review, 8:129-136.

Stirling, R., Stirling Air Engine and The Heat Regenarator, Patent no 4081, 1816.

Urieli, I. and Berchowitz, D. M. (1984). Stirling Cycle Engine Analysis. (1. Edition). Bristol: Adam Hilger.

Weenen, F. L. V. 1947. “The Construction of the Philips air engine”, Philips Technical Review, 9(5):125-134. 